\title{
ANALISIS EFEKTIFITAS MESIN PEWARNA SERAT OPTIK DENGAN METODE OVERALL EQUIPMENT EFFECTIVENESS (OEE) (STUDI KASUS PT. VOKSEL ELECTRIC TBK.)
}

\author{
Ilham Saharani ${ }^{1}$, Sukanta ${ }^{2}$ \\ Program Studi Tenik Industri, Universitas Singaperbangsa Karawang \\ ilham.saharani17012@student.unsika.ac.id ${ }^{1}$, sukanta@ft.unsika.ac.id ${ }^{2}$
}

Submitted January 18, 2021; Revised January 29, 2021; Accepted February 2, 2021

\begin{abstract}
Abstrak
Untuk mendukung sistem manufaktur maka kinerja peralatan yang digunakan harus diperhatikan agar dapat dimanfaatkan dengan sebaik-baiknya. PT. Voksel Electric Tbk. merupakan perusahaan yang bergerak dalam bidang usaha industri kelistrikan dan telekomunikasi. Proses produksi PT. Voksel Electric Tbk. tidak terlepas dari alat atau mesin produksi yang mempunyai ketersediaan waktu dan kinerja serta siap memenuhi pesanan perusahaan. Salah satu alat untuk mengukur efektivitas suatu mesin adalah dengan menggunakan Overall Equipment Effectiveness (OEE), yang telah diakui di seluruh dunia untuk mengukur efektivitas mesin. Tujuan dari penelitian ini adalah untuk mengetahui tingkat efektivitas dari mesin CETC 02 Coloring FO pada lini coloring serta penyebabnya sehingga perusahaan dapat mengambil keputusan yang tepat untuk memperbaikinya berdasarkan hasil yang diperoleh. Dengan tingkat availability 67\%, tingkat performance 95\%, dan tingkat quality $100 \%$ didapatkan total efektifitas mesin keseluruhan dalam satu shift kerja selama 11 hari dari tanggal 14 Januari 2020 sampai 29 Januari 2020 adalah 63\% yang berada di atas batas kewajaran standar benchmark Japan Institute of Plant Management (JIPM) yaitu 60\%. Tingkat availability menyumbang persentase paling kecil karena disebabkan oleh banyak hal yang mengharuskan mesin berhenti, baik yang disengaja atau tidak disengaja seperti pada tanggal 22 Januari 2020 tercatat waktu downtime paling besar yaitu 360 menit karena saat itu mesin bermasalah dan tidak boleh dioperasikan sebelum ditangani oleh bagian maintenance.
\end{abstract}

Kata Kunci : Overall Equipment Effectiveness (OEE), Availability Rate, Performance Rate, Quality Rate

\begin{abstract}
To support the manufacturing system, the performance of the equipment used must be considered so that it can be used properly. PT. Voksel Electric Tbk. is a company engaged in the electricity and telecommunications industry. The production process of PT. Voksel Electric Tbk. inseparable from production tools or machines that have time and performance availability and are ready to fulfill company orders. One of the tools to measure the effectiveness of a machine is to use Overall Equipment Effectiveness (OEE), which has been recognized worldwide to measure machine effectiveness. The purpose of this study is to determine the level of effectiveness of the CETC 02 Coloring FO machine in the coloring line and its causes so that the company can make the right decision to fix it based on the results obtained. With $67 \%$ availability, $95 \%$ performance level, and $100 \%$ quality level, the total effectiveness of the entire machine in one work shift for 11 days from January 142020 to January 292020 is 63\% which is above the fairness limit of the Japan Institute benchmark standard. of Plant Management (JIPM), namely 60\%. The availability level accounts for the smallest percentage because it is caused by many things that require the machine to stop, whether intentional or unintentional, such as on January 22, 2020, the greatest downtime was recorded at 360 minutes because at that time the machine had a problem and could not be operated before it was handled by the maintenance department.
\end{abstract}

Key Words : Overall Equipment Effectiveness (OEE), Availability Rate, Performance Rate, Quality Rate 


\section{PENDAHULUAN}

Selain perkembangan pendidikan, kegiatan industri juga mengalami perubahan yang ditandai dengan revolusi industri. Sejarah revolusi industri dimulai dari industri 1.0, 2.0, 3.0 hingga industri 4.0. Tahap industri adalah perubahan nyata atas perubahan yang ada. Industri 1.0 dicirikan oleh keefektifan dan efisiensi mekanisasi produksi untuk mendukung aktivitas manusia, Industri 2.0 dicirikan oleh produksi massal dan standarisasi kualitas, dan Industri 3.0 dicirikan oleh kustomisasi massal dan fleksibilitas otomatisasi dan pembuatan berbasis robot. Kemudian, Industri 4.0 menggantikan Industri 3.0 yang ditandai dengan fisika siber dan kolaborasi manufaktur. Istilah "Industri 4.0 " berasal dari proyek yang diprakarsai oleh pemerintah Jerman untuk mempromosikan komputerisasi manufaktur [1].

Di era revolusi 4.0, persaingan di industri semakin ketat.. Hal tersebut menuntut perusahaan untuk lebih memperhatikan kepuasan pelanggan dengan tetap menjaga efisiensi dalam proses produksinya [2]. Perusahaan menghadapi tantangan untuk dapat mengoptimalkan seluruh sumber dayanya untuk menghilangkan berbagai bentuk pemborosan dan mencegah kemacetan produksi akibat kegagalan mesin [3]. Layaknya manusia, kondisi mesin dan peralatan akan menurunkan kemampuannya dalam menjalankan tugasnya seiring bertambahnya usia. Selain masalah usia sebagai faktor internal, terdapat juga beberapa faktor eksternal yang mempengaruhi kemampuan kerja mesin. Menurut penelitian Dhilon (2004), beberapa faktor tersebut antara lain kesalahan pengoperasian mesin, input bahan baku yang tidak tepat, dan pemasangan alat bantu yang tidak tepat atau alasan lain yang menyebabkan mesin gagal berfungsi dengan baik. Seringkali terdapat permasalahan yang mempengaruhi hasil keluaran mesin, sehingga banyak ditemukan cacat (unqualified) dan tujuan produksi yang ditentukan tidak dapat tercapai. Permasalahan umum pada mesin ini antara lain material (resin) yang digunakan untuk mengikat material tidak merata sesuai dengan lebar material, sehingga mesin harus dimatikan untuk perbaikan (maintenance). Tidak terlalu lengket (terikat) seperti yang diharapkan, inilah material yang dihasilkan pada proses sebelumnya [4].

Setiap perusahaan harus selalu melakukan perbaikan terus menerus di setiap departemen agar mampu bersaing terutama di lini produksi, karena ini adalah bagian terpenting dari perusahaan. Jalur produksi penting. Dengan perbaikan pekerjaan maka perusahaan dapat bertahan dan mencapai tujuan dan sasaran yang telah ditetapkan. Untuk mendukung sistem manufaktur maka kinerja peralatan yang digunakan harus diperhatikan agar dapat dimanfaatkan dengan sebaik-baiknya [3].

PT. Voksel Electric Tbk. merupakan perusahaan industri kelistrikan dan telekomunikasi. Proses produksi PT. Voksel Electric Tbk. tidak terlepas dari alat atau mesin produksi yang mempunyai ketersediaan waktu dan kinerja serta siap memenuhi pesanan perusahaan. PT. Voksel Electric Tbk. ini berisikan pabrik yang terdiri dari beberapa bagian bangunan produksi salah satunya produksi divisi Telecommunication Cable departemen Optical Fiber Cable (FO). Pada departemen FO terdapat lini yang berperan penting dalam proses produksi yaitu lini coloring yang ditunjukkan pada Gambar 1, pada lini ini disediakan delapan mesin Coloring yang terdiri dari empat mesin manual dan empat mesin otomatis, namun di lapangan yang bisa terpakai hanya enam mesin yang terdiri dari tiga mesin manual dan tiga mesin otomatis, satu mesin manual rusak dan sudah dipindahkan sedangkan satu mesin otomatis rusak 
menunggu untuk teknisi produsen datang memperbaiki. Operator pada lini ini berjumlah empat orang, tiga orang memegang enam mesin dengan masingmasing satu mesin manual dan satu mesin otomatis, sedangkan satu orang sebagai quality control.

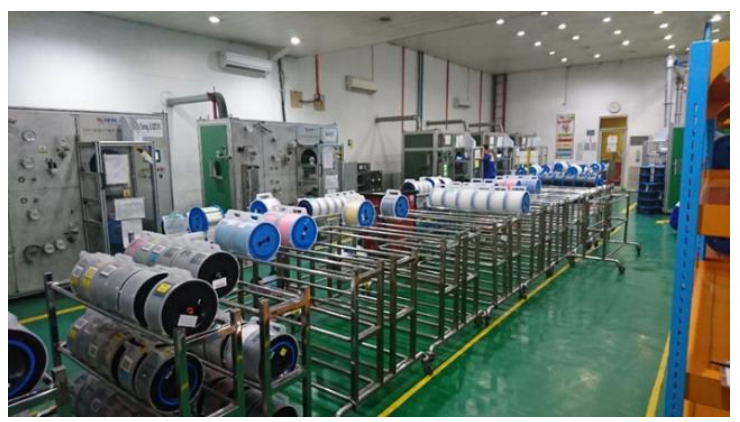

Gambar 1. Coloring Line Departemen Optical Fiber Cable

Salah satu alat untuk mengukur efektivitas suatu mesin adalah metode Overall Equipment Effectiveness (OEE), yang telah diakui di seluruh dunia untuk mengukur efektivitas mesin [3]. OEE merupakan indikator yang menitikberatkan pada efisiensi pelaksanaan operasi produksi [5]. Menurut Nayak (2013), OEE merupakan hasil perhitungan faktor-faktor yang berkontribusi pada suatu produk seperti ketersediaan, kinerja dan kualitas [6]. Evaluasi terkait nilai OEE mengikuti standar global adalah: availability ratio $90 \%$, performance ratio $95 \%$, dan quality ratio $99 \%$, sehingga nilai ideal OEE peralatan adalah $85 \%$ [3].

Awalnya, OEE adalah bentuk perbaikan dari Total Production Maintenance (TPM) yang dikembangkan oleh Seiichi Nakajima di Japan Institute of Plan Maintenance untuk mencapai kinerja yang diinginkan tanpa kerugian [7]. Menurut Nakajima (1988), tujuan dari TPM adalah untuk memastikan bahwa semua peralatan atau mesin dalam kondisi kerja yang baik untuk menghindari kerusakan dan keterlambatan dalam proses pembuatan [8]. Dengan kata lain, tidak ada scrap atau cacat produksi, tidak ada kerusakan, tidak ada kecelakaan, dan tidak ada waste selama proses produksi atau proses konversi. Dibandingkan dengan waktu yang tersedia, total waktu yang terbuang dapat memungkinkan manajer memperoleh kinerja produksi dan pemeliharaan yang sebenarnya, dan membantu berkonsentrasi untuk menangani kerugian yang lebih besar. OEE adalah jumlah keefektifan yang dimiliki perangkat atau mesin. Dihitung dengan memperoleh OEE dari ketersediaan peralatan, efisiensi pelaksanaan proses, dan rasio kualitas produk [3].

Untuk menganalisis nilai OEE yang diperoleh, dapat digunakan standar benchmark yang ditetapkan oleh Japan Institute of Plant Maintenance (JIPM) yang telah dipraktekan secara luas di seluruh dunia. Berikut OEE Benchmark [7]:

1. Nilai OEE $=100 \%$, produksi dianggap sempurna, berarti hanya memproduksi produk tanpa cacat, bekerja dalam performance yang cepat, dan tidak ada downtime.

2. Nilai $\mathrm{OEE}=85 \%$, produksi dianggap kelas dunia. Bagi banyak perusahaan, skor ini merupakan skor yang cocok untuk dijadikan goal jangka panjang.

3. Nilai $\mathrm{OEE}=60 \%$, produksi dianggap wajar, tapi menunjukkan ada ruang yang besar untuk improvement.

4. Nilai $\mathrm{OEE}=40 \%$, produksi dianggap memiliki skor yang rendah, tapi dalam kebanyakan kasus dapat dengan mudah di-improve melalui pengukuran langsung (misalnya dengan menelusuri alasan-alasan downtime dan menangani sumber-sumber penyebab downtime secara satu per satu).

Tujuan dari penelitian ini adalah untuk mengetahui tingkat efektivitas dari mesin yang ada pada lini coloring serta penyebabnya sehingga perusahaan dapat mengambil keputusan yang tepat untuk 
memperbaikinya berdasarkan hasil yang diperoleh.

\section{METODE PENELITIAN}

Tipe penelitian ini deskriptif, berdasarkan pada pertanyaan dasar bagaimana. Kita tidak puas bila hanya mengetahui apa masalah efektivitas mesin, tetapi ingin mengetahui juga bagaimana peristiwa tersebut terjadi.

Pada departemen FO proses produksi Coloring yang merupakan proses awal dalam pembuatan kabel optik yaitu proses pewarnaan serat optik, fokus pada proses produksi yang dikerjakan oleh mesin CETC 02 Coloring FO yang ditunjukkan pada Gambar 2.

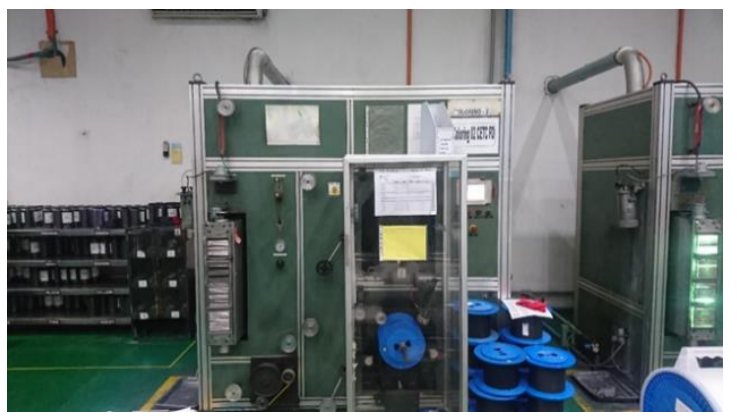

Gambar 2. Mesin CETC 02 Coloring FO

Perangkat penelitian yang akan digunakan untuk mengumpulkan data pada penelitian ini adalah lembar observasi yaitu membuat lembar pencatatan berdasarkan kebutuhan data penelitian untuk mencatat hasil pengamatan terkait OEE di lapangan.

Penelitian dimulai dengan pengumpulan data waktu yang mempengaruhi kegiatan produksi, yaitu waktu setup, downtime, dan proses pada mesin CETC 02 Coloring FO. Pengumpulan data dilakukan dengan pencatatan pada lembar observasi yang sudah dibuat.

Setelah data terkumpul selanjutnya dilakukan perhitungan. Perhitungan nilai OEE adalah pengolahan data dengan menggunakan metode Overall Equipment Effectiveness (OEE). Setiap perusahaan berharap peralatan produksinya dapat mencapai $100 \%$ operasi tanpa mati, beroperasi pada kinerja $100 \%$ tanpa mengurangi kecepatan, dan mencapai $100 \%$ keluaran tanpa menghasilkan pemborosan. Faktanya, ini sulit dicapai, tetapi bukan tidak mungkin. Menghitung OEE adalah cara untuk memaksimalkan kinerja peralatan produksi. Langkahlangkah yang dilakukan adalah sebagai berikut:

\section{Availability Rate}

Availability Rate (VA) adalah rasio yang menunjukkan waktu yang tersedia untuk aktivitas pengoperasian mesin [3]. Data yang dibutuhkan adalah: waktu direncanakan dan waktu berjalan. Waktu yang direncanakan mengacu pada waktu mesin siap untuk dijalankan dalam 1 hari [9]. Pada proses produksi mesin Coloring 02 CETC FO, diamati setiap setup time dan downtime yang terjadi dan mencatat waktunya seperti, pasang serat optik pada mesin, atur kecepatan dan rata kiri kanan posisi serat optik, cuci dies, cuci quartube, mesin rusak, penambahan tinta, pergantian tinta, dan lain-lain dalam satu shift kerja.

$\mathrm{VA}=$ (waktu operasional - (waktu setup + waktu downtime)) / waktu operasional $\mathrm{x} 100 \%$

2. Performance Rate

Performance Rate (PE) merupakan rasio yang menunjukkan kemampuan peralatan dalam memproduksi barang [3]. Data yang dibutuhkan adalah data run time dan data cycle time. Waktu siklus mengacu pada waktu mesin bekerja untuk menghasilkan 1 unit produk [9]. Dicatat jumlah kumparan (bobbin) warna yang dihasilkan oleh mesin Coloring 02 CETC FO memiliki panjang bervariasi mulai dari $12,1 \mathrm{Km}$, $25,2 \mathrm{Km}$, dan $50,4 \mathrm{Km}$ serta waktu siklus 1 menit setiap $\mathrm{Km}$ dalam satu shift kerja. 
$\mathrm{PE}=($ output $\mathrm{x}$ ideal cycle time $) /$ waktu proses $\mathrm{x} 100 \%$

3. Quality Rate

Quality Rate (RQ) merupakan rasio yang menunjukkan kemampuan peralatan untuk menghasilkan produk yang memenuhi standar [3]. Data yang dibutuhkan, yaitu volume produksi per hari dikurangi jumlah cacat per hari [9]. Dari setiap produk yang dihasilkan oleh mesin Coloring 02 CETC FO, dihitung jumlah produk yang ditolak (not good) dalam satu shift kerja.

$\mathrm{RQ}=$ finished goods / jumlah unit yang diproses x $100 \%$

4. Overall Equipment Effectiveness

Perhitungan Overall Equipment Effectiveness (OEE) didasarkan pada tiga faktor utama yaitu availability rate, performance rate, dan quality rate.

$$
\mathrm{OEE}=\mathrm{VA} \times \mathrm{PE} \times \mathrm{RQ}
$$

\section{HASIL DAN PEMBAHASAN}

Dengan pengambilan data menggunakan lembar observasi pada Tabel 1 yang mencatat setup time, downtime, jumlah produk dihasilkan, dan jumlah produk not good selama 11 hari didapatkan hasil seperti yang ditunjukkan Tabel 1 sampai Tabel 11.

Tabel 1. Lembar Observasi 14 Januari 2020

\begin{tabular}{|c|c|c|c|c|c|}
\hline Tanggal & 14 Januari 2020 & Operator & Rohmad & Warna & Puth \\
\hline \multicolumn{5}{|c|}{ Mesin CETC 02 Coloring FO } \\
\hline $\begin{array}{c}\text { Bobbin } \\
\text { Natural ke }\end{array}$ & $\begin{array}{c}\text { Bobbin Warna } \\
\text { ke }\end{array}$ & $\begin{array}{c}\text { Waktu } \\
\text { Setup }\end{array}$ & Downtime & $\begin{array}{c}\text { Keterangan } \\
\text { Downtime }\end{array}$ & $\begin{array}{c}\text { Waktu } \\
\text { Proses }\end{array}$ \\
\hline 1 & 1 & 3 & 5 & Cuci Quartube & 25.57 \\
\hline & 2 & 2 & & & 26.04 \\
\hline 2 & 3 & 3 & & & 26.09 \\
\hline & 4 & 2 & & & 26.08 \\
\hline 3 & 5 & 3 & & & 26.01 \\
\hline & 6 & 2 & & & 26.02 \\
\hline 4 & 7 & 3 & & & 26.16 \\
\hline & 8 & 2 & & & 26.12 \\
\hline 5 & 9 & 3 & & & 26.03 \\
\hline & 10 & 2 & & & 26.09 \\
\hline
\end{tabular}

Tabel 2. Lembar Observasi 15 Januari 2020

\begin{tabular}{|c|c|c|c|l|l|}
\hline Tanggal & 15 Januari & Operator & Rohmad & Warna & Putih \\
\hline \multicolumn{5}{|c|}{ Mesin CETC 02 Coloring FO } \\
\hline $\begin{array}{c}\text { Bobbin } \\
\text { Natural ke }\end{array}$ & $\begin{array}{c}\text { Bobbin Warna } \\
\text { ke }\end{array}$ & $\begin{array}{c}\text { Waktu } \\
\text { Setup }\end{array}$ & Downtime & $\begin{array}{c}\text { Keterangan } \\
\text { Downtime }\end{array}$ & $\begin{array}{c}\text { Waktu } \\
\text { Proses }\end{array}$ \\
\hline 1 & 1 & 3 & 254 & $\begin{array}{c}\text { mesin tidak } \\
\text { terpakai karena } \\
\text { stock masih } \\
\text { banyak }\end{array}$ & \\
\hline & & & 2 & Refill tinta & 51.76 \\
\hline & & & 2 & Cuci dies & \\
\hline
\end{tabular}

Tabel 3. Lembar Observasi 17 Januari 2020

\begin{tabular}{|c|c|c|c|c|c|}
\hline Tanggal & 17 Januari 2020 & Operator & Rohmad & Warna & Kuning \\
\hline \multicolumn{7}{|c|}{ Mesin CETC 02 Coloring } & FO \\
\hline $\begin{array}{c}\text { Bobbin } \\
\text { Natural ke }\end{array}$ & $\begin{array}{c}\text { Bobbin Warna } \\
\text { ke }\end{array}$ & $\begin{array}{c}\text { Waktu } \\
\text { Setup }\end{array}$ & Downtime & $\begin{array}{c}\text { Keterangan } \\
\text { Downtime }\end{array}$ & $\begin{array}{c}\text { Waktu } \\
\text { Proses }\end{array}$ \\
\hline 1 & 1 & 3 & 82 & $\begin{array}{c}\text { Bersih-bersih } \\
\text { lokasi kerja }\end{array}$ & 51.23 \\
\hline 2 & 2 & 3 & 13 & $\begin{array}{c}\text { Menunggu } \\
\text { work order }\end{array}$ & 51.25 \\
\hline 3 & 3 & 3 & 7 & $\begin{array}{c}\text { Mesin } \\
\text { bermasalah }\end{array}$ & 25.59 \\
\hline & 4 & 4 & 9 & $\begin{array}{c}\text { Cuci quartube } \\
\text { dan dies }\end{array}$ & 26.35 \\
\hline
\end{tabular}

Tabel 4. Lembar Observasi 20 Januari 2020

\begin{tabular}{|c|c|c|c|c|c|}
\hline Tanggal & 20 Januari 2020 & Operator & Anggit & Warna & Turquoise \\
\hline \multicolumn{7}{|c|}{ Mesin CETC 02 Coloring } & FO \\
\hline $\begin{array}{c}\text { Bobbin } \\
\text { Natural ke }\end{array}$ & $\begin{array}{c}\text { Bobbin Warna } \\
\text { ke }\end{array}$ & $\begin{array}{c}\text { Waktu } \\
\text { Setup }\end{array}$ & Downtime & $\begin{array}{c}\text { Keterangan } \\
\text { Downtime }\end{array}$ & $\begin{array}{c}\text { Waktu } \\
\text { Proses }\end{array}$ \\
\hline 1 & 1 & 19 & 105 & $\begin{array}{c}\text { Bersih-bersih } \\
\text { lokasi kerja }\end{array}$ & 27.12 \\
\hline & 2 & 2 & 6 & $\begin{array}{c}\text { Ganti busa } \\
\text { penutup sinar } \\
\text { UV }\end{array}$ & 26.52 \\
\hline 2 & 3 & 3 & 28 & $\begin{array}{c}\text { Refill tinta, } \\
\text { cuci dies dan } \\
\text { quartube }\end{array}$ & 26.35 \\
\hline & 4 & 2 & & & 27.13 \\
\hline 3 & 5 & 3 & & & 26.51 \\
\hline & 6 & 1 & & & 29.14 \\
\hline 4 & 7 & 12 & & & 27.03 \\
\hline & 8 & 2 & & & \\
\hline
\end{tabular}

Tabel 5. Lembar Observasi 21 Januari 2020

\begin{tabular}{|c|c|c|c|c|r|r|}
\hline Tanggal & 21 Januari 2020 & Operator & Anggit & Warna & Turquoise \\
\hline \multicolumn{5}{|c|}{ Mesin CETC 02 Coloring FO } \\
\hline $\begin{array}{c}\text { Bobbin } \\
\text { Natural ke }\end{array}$ & $\begin{array}{c}\text { Bobbin Warna } \\
\text { ke }\end{array}$ & $\begin{array}{c}\text { Waktu } \\
\text { Setup }\end{array}$ & Downtime & $\begin{array}{c}\text { Keterangan } \\
\text { Downtime }\end{array}$ & $\begin{array}{r}\text { Waktu } \\
\text { Proses }\end{array}$ \\
\hline 1 & 1 & 3 & 21 & $\begin{array}{l}\text { Refill tinta dan } \\
\text { cuci quartube }\end{array}$ & 26.21 \\
\hline & 2 & 2 & 2 & Refill tinta & 26.18 \\
\hline 2 & 3 & 3 & & & 15.31 \\
\hline 3 & 4 & 3 & & & 17.32 \\
\hline 4 & 5 & 4 & & & 26.44 \\
\hline & 6 & 1 & & & 26.41 \\
\hline 5 & 7 & 3 & & & 27.3 \\
\hline & 8 & 1 & & & 26.52 \\
\hline 6 & 9 & 3 & & & 27.04 \\
\hline & 10 & 2 & & & 26.58 \\
\hline & 11 & 2 & & & 26.4 \\
\hline
\end{tabular}


Tabel 6. Lembar Observasi 22 Januari 2020

\begin{tabular}{|c|c|c|c|c|c|}
\hline Tanggal & 22 Januari 2020 & Operator & Anggit & Warna & Kuning \\
\hline \multicolumn{5}{|c|}{ Mesin CETC 02 Coloring FO } \\
\hline $\begin{array}{c}\text { Bobbin } \\
\text { Natural ke }\end{array}$ & $\begin{array}{c}\text { Bobbin Warna } \\
\text { ke }\end{array}$ & $\begin{array}{c}\text { Waktu } \\
\text { Setup }\end{array}$ & Downtime & $\begin{array}{c}\text { Keterangan } \\
\text { Downtime }\end{array}$ & $\begin{array}{c}\text { Waktu } \\
\text { Proses }\end{array}$ \\
\hline 1 & 1 & 3 & 29 & $\begin{array}{c}\text { Mesin } \\
\text { bermasalah }\end{array}$ & 25.57 \\
\hline 2 & 2 & 3 & 12 & Cuci dies & 26.04 \\
\hline & & 319 & $\begin{array}{c}\text { Mesin tidak } \\
\text { boleh } \\
\text { beroperasi }\end{array}$ & \\
\hline
\end{tabular}

Tabel 7. Lembar Observasi 23 Januari 2020

\begin{tabular}{|c|c|c|c|c|r|}
\hline Tanggal & 23 Januari 2020 & Operator & Anggit & Warna & Putih \\
\hline \multicolumn{7}{|c|}{ Mesin CETC 02 Coloring FO } \\
\hline $\begin{array}{c}\text { Bobbin } \\
\text { Natural ke }\end{array}$ & $\begin{array}{c}\text { Bobbin Warna } \\
\text { ke }\end{array}$ & $\begin{array}{c}\text { Waktu } \\
\text { Setup }\end{array}$ & Downtime & $\begin{array}{c}\text { Keterangan } \\
\text { Downtime }\end{array}$ & $\begin{array}{c}\text { Waktu } \\
\text { Proses }\end{array}$ \\
\hline 1 & 1 & 3 & 1 & Refill tinta & 26.4 \\
\hline 2 & 2 & 2 & & & 26.35 \\
\hline 3 & 3 & 3 & & & 26.53 \\
\hline & 4 & 1 & & & 26.47 \\
\hline 4 & 5 & 2 & & & 27 \\
\hline & 6 & 1 & & & 25.34 \\
\hline 5 & 7 & 2 & & & 25.44 \\
\hline & 8 & 10 & & & 26.59 \\
\hline 6 & 9 & 3 & & & 26.3 \\
\hline & 10 & 1 & & & 26.4 \\
\hline
\end{tabular}

Tabel 8. Lembar Observasi 24 Januari 2020

\begin{tabular}{|c|c|c|c|c|r|}
\hline Tanggal & 24 Januari 2020 & Operator & Anggit & Warna & Turquoise \\
\hline \multicolumn{7}{|c|}{ Mesin CETC 02 Coloring FO } \\
\hline $\begin{array}{c}\text { Bobbin } \\
\text { Natural ke }\end{array}$ & $\begin{array}{c}\text { Bobbin Warna } \\
\text { ke }\end{array}$ & $\begin{array}{c}\text { Waktu } \\
\text { Setup }\end{array}$ & Downtime & $\begin{array}{c}\text { Keterangan } \\
\text { Downtime }\end{array}$ & $\begin{array}{c}\text { Waktu } \\
\text { Proses }\end{array}$ \\
\hline 1 & 1 & 3 & 80 & Audit & 51.32 \\
\hline 2 & 2 & 3 & & & 51.4 \\
\hline 3 & 3 & 3 & & & 51.45 \\
\hline 4 & 4 & 4 & & & 26.48 \\
\hline & 5 & 3 & & & 26.13 \\
\hline
\end{tabular}

Tabel 9. Lembar Observasi 27 Januari 2020

\begin{tabular}{|c|c|c|c|c|c|c|}
\hline Tanggal & 27 Januari 2020 & Operator & Aris & Warna & Turquoise \\
\hline \multicolumn{5}{|c|}{ Mesin CETC 02 Coloring FO } \\
\hline $\begin{array}{c}\text { Bobbin } \\
\text { Natural ke }\end{array}$ & $\begin{array}{c}\text { Bobbin Warna } \\
\text { ke }\end{array}$ & $\begin{array}{c}\text { Waktu } \\
\text { Setup }\end{array}$ & Downtime & $\begin{array}{c}\text { Keterangan } \\
\text { Downtime }\end{array}$ & $\begin{array}{r}\text { Waktu } \\
\text { Proses }\end{array}$ \\
\hline 1 & 1 & 7 & 155 & $\begin{array}{c}\text { Bersih-bersih } \\
\text { bkasi kerja }\end{array}$ & 26.2 \\
\hline & 2 & 2 & 95 & $\begin{array}{c}\text { Mesin } \\
\text { bermasalah dan } \\
\text { diperbaiki }\end{array}$ & 28.25 \\
\hline 2 & 3 & 5 & 6 & $\begin{array}{c}\text { Mesin } \\
\text { bermasalah, } \\
\text { putaran tidak } \\
\text { sesuai }\end{array}$ & \\
\hline & & & 4 & Refill tinta & 29.32 \\
\hline
\end{tabular}

Tabel 10. Lembar Observasi 28 Januari 2020

\begin{tabular}{|c|c|c|c|c|r|}
\hline Tanggal & 28 Januari 2020 & Operator & Aris & Warna & Turquoise \\
\hline \multicolumn{7}{|c|}{ Mesin CETC 02 Coloring } & FO \\
\hline $\begin{array}{c}\text { Bobbin } \\
\text { Natural ke }\end{array}$ & $\begin{array}{c}\text { Bobbin Warna } \\
\text { ke }\end{array}$ & $\begin{array}{c}\text { Waktu } \\
\text { Setup }\end{array}$ & Downtime & $\begin{array}{c}\text { Keterangan } \\
\text { Downtime }\end{array}$ & $\begin{array}{c}\text { Waktu } \\
\text { Proses }\end{array}$ \\
\hline 1 & 1 & 3 & 15 & Cuci quartube & 26.27 \\
\hline & 2 & 2 & 17 & $\begin{array}{c}\text { Cuci dies dan } \\
\text { quartube }\end{array}$ & \\
& 3 & 3 & & & 27.2 \\
\hline 2 & 4 & 5 & & & 27.31 \\
\hline & 5 & 5 & & & 27.15 \\
\hline 3 & 6 & 2 & & & 27.45 \\
\hline & 7 & 4 & & & 28.47 \\
\hline 4 & 8 & 2 & & & 28.12 \\
\hline & 9 & 5 & & & 27.53 \\
\hline 5 & 10 & 2 & & & 28.41 \\
\hline
\end{tabular}

Tabel 11. Lembar Observasi 29 Januari 2020

\begin{tabular}{|c|c|c|c|c|r|}
\hline Tanggal & 29 Januari 2020 & Operator & Aris & Warna & Turquoise \\
\hline \multicolumn{7}{|c|}{ Mesin CETC 02 Coloring } & FO \\
\hline $\begin{array}{c}\text { Bobbin } \\
\text { Natural ke }\end{array}$ & $\begin{array}{c}\text { Bobbin Warna } \\
\text { ke }\end{array}$ & $\begin{array}{c}\text { Waktu } \\
\text { Setup }\end{array}$ & Downtime & $\begin{array}{c}\text { Keterangan } \\
\text { Downtime }\end{array}$ & $\begin{array}{c}\text { Waktu } \\
\text { Proses }\end{array}$ \\
\hline 1 & 1 & 5 & 15 & Cuci quartube & 27.17 \\
\hline & 2 & 1 & & & 27.42 \\
\hline 2 & 3 & 4 & & & 27.59 \\
\hline & 4 & 1 & & & 28.04 \\
\hline 3 & 5 & 3 & & & 29.22 \\
\hline & 6 & 1 & & & 27.44 \\
\hline 4 & 7 & 4 & & & 28.06 \\
\hline & 8 & 1 & & & 28.14 \\
\hline 5 & 9 & 17 & & & 27.11 \\
\hline & 10 & 1 & & & 27.43 \\
\hline
\end{tabular}

Good atau not good nya produk kabel optik yang sudah selesai diwarnai dapat diketahui melalui pengecekan attenuation (redaman) dalam satuan $\mathrm{db} / \mathrm{Km}$ menggunakan alat Optical Domain Reflecto Meter (OTDR). OTDR digunakan untuk mendapatkan gambaran visual dari atenuasi serat sepanjang link yang digambar pada layar, dimana jarak diplot pada sumbu $\mathrm{X}$ dan atenuasi diplot pada sumbu Y [10]. Nilai minimal redaman kabel optik pada perusahaan adalah 0,215 $\mathrm{db} / \mathrm{Km}$.

Dikarenakan hasil good atau not good nya produk hanya dapat dilihat dari laporan bagian quality control yang berbeda lokasi dengan tempat pengamatan, maka data diambil melalui wawancara pada akhir bulan Januari. Setelah bertanya pada bagian quality control mengenai data baik 
buruknya produk, didapatkan hasil semuanya baik pada tanggal-tanggal tersebut. Hal ini juga diperkuat oleh pernyataan salah satu staff produksi Bapak Bambang bahwa "proses pewarnaan kabel optik sangat minim NG".
Selanjutnya dibuat tabel rekapitulasi agar mudah untuk dilakukan perhitungan availability rate, performance rate, dan quality rate dapat dilihat pada Tabel 12 .

Tabel 12. Rekapitulasi Hasil Pengumpulan Data

\begin{tabular}{|c|c|c|c|c|c|c|c|}
\hline Tanggal & $\begin{array}{c}\text { Waktu } \\
\text { Operasional } \\
\text { (menit) }\end{array}$ & $\begin{array}{c}\text { Waktu } \\
\text { Setup } \\
\text { (menit) }\end{array}$ & $\begin{array}{c}\text { Jumlah } \\
\text { Downtime }\end{array}$ & $\begin{array}{c}\text { Waktu } \\
\text { Downtime }\end{array}$ & $\begin{array}{c}\text { Jumlah } \\
\text { Unit yang } \\
\text { Diproses } \\
\text { (bobbin) }\end{array}$ & $\begin{array}{c}\text { Waktu } \\
\text { Proses } \\
\text { (menit) }\end{array}$ & $\begin{array}{c}\text { Produk } \\
\text { Cacat } \\
\text { (bobbin) }\end{array}$ \\
\hline 14 Januari 2020 & 420 & 25 & 1 & 5 & 10 & 260 & 0 \\
\hline 15 Januari 2020 & 420 & 3 & 3 & 258 & 2 & 52 & 0 \\
\hline 17 Januari 2020 & 420 & 13 & 4 & 111 & 6 & 154 & 0 \\
\hline 20 Januari 2020 & 420 & 44 & 3 & 139 & 8 & 216 & 0 \\
\hline 21 Januari 2020 & 420 & 27 & 2 & 23 & 10 & 272 & 0 \\
\hline 22 Januari 2020 & 420 & 6 & 3 & 360 & 2 & 52 & 0 \\
\hline 23 Januari 2020 & 420 & 28 & 1 & 1 & 10 & 263 & 0 \\
\hline 24 Januari 2020 & 420 & 16 & 1 & 80 & 8 & 207 & 0 \\
\hline 27 Januari 2020 & 420 & 17 & 4 & 260 & 3 & 84 & 0 \\
\hline 28 Januari 2020 & 420 & 33 & 2 & 32 & 10 & 274 & 0 \\
\hline 29 Januari 2020 & 420 & 38 & 1 & 15 & 10 & 278 & 0 \\
\hline
\end{tabular}

Pada Tabel 13 hanya berisi total dari setiap elemen variabel perhari dalam 11 hari pengamatan. Perlu diketahui penjumlahan waktu proses dilakukan dengan pembulatan untuk memudahkan perhitungan. Langkah selanjutnya adalah perhitungan variabel-variabel untuk OEE.

\section{Perhitungan Availability Rate (VA)}

Variabel pertama adalah availability rate (VA). Menggunakan rumus dapat diberikan contoh perhitungan VA pada tanggal 14 Januari 2020 adalah sebagai berikut:

$$
\mathrm{VA}=((420-(25+5))) / 420 \times 100 \%
$$

$$
\begin{aligned}
\mathrm{VA} & =((390)) / 420 \times 100 \% \\
\mathrm{VA} & =0.929 \times 100 \% \\
\mathrm{VA} & =93 \%
\end{aligned}
$$

Angka persentase ini menunjukkan waktu mesin terpakai dari 420 menit waktu operasional mesin. Waktu proses berbeda dengan waktu operasional mesin dikurangi waktu setup dan downtime karena satu orang mengerjakan dua mesin secara bergantian.

Hasil perhitungan availability rate dari tanggal 14 Januari 2020 sampai tanggal 29 Januari 2020 tertera pada Tabel 13.

Tabel 13. Hasil Perhitungan Availability Rate

\begin{tabular}{|c|c|c|c|c|c|c|c|c|}
\hline Tanggal & $\begin{array}{c}\text { Waktu } \\
\text { Operasional } \\
\text { (menit) }\end{array}$ & $\begin{array}{c}\text { Waktu } \\
\text { Setup } \\
\text { (menit) }\end{array}$ & $\begin{array}{c}\text { Jumlah } \\
\text { Downtime }\end{array}$ & $\begin{array}{c}\text { Waktu } \\
\text { Downtime }\end{array}$ & $\begin{array}{c}\text { Jumlah } \\
\text { Unit yang } \\
\text { Diproses } \\
\text { (bobbin })\end{array}$ & $\begin{array}{c}\text { Waktu } \\
\text { Proses } \\
\text { (menit) }\end{array}$ & $\begin{array}{c}\text { Produk } \\
\text { Cacat } \\
\text { (bobbin) }\end{array}$ & Availability \\
\hline 14 Januari 2020 & 420 & 25 & 1 & 5 & 10 & 260 & 0 & $93 \%$ \\
\hline 15 Januari 2020 & 420 & 3 & 3 & 258 & 2 & 52 & 0 & $38 \%$ \\
\hline 17 Januari 2020 & 420 & 13 & 4 & 111 & 6 & 154 & 0 & $70 \%$ \\
\hline 20 Januari 2020 & 420 & 44 & 3 & 139 & 8 & 216 & 0 & $56 \%$ \\
\hline 21 Januari 2020 & 420 & 27 & 2 & 23 & 10 & 272 & 0 & $88 \%$ \\
\hline 22 Januari 2020 & 420 & 6 & 3 & 360 & 2 & 52 & 0 & $13 \%$ \\
\hline 23 Januari 2020 & 420 & 28 & 1 & 1 & 10 & 263 & 0 & $93 \%$ \\
\hline 24 Januari 2020 & 420 & 16 & 1 & 80 & 8 & 207 & 0 & $77 \%$ \\
\hline 27 Januari 2020 & 420 & 17 & 4 & 260 & 3 & 84 & 0 & $34 \%$ \\
\hline 28 Januari 2020 & 420 & 33 & 2 & 32 & 10 & 274 & 0 & $85 \%$ \\
\hline 29 Januari 2020 & 420 & 38 & 1 & 15 & 10 & 278 & 0 & $87 \%$ \\
\hline
\end{tabular}


2. Perhitungan Performance Rate (PE)

Variabel kedua adalah performance rate (PE). Menggunakan rumus dapat diberikan contoh perhitungan PE pada tanggal 14 Januari 2020 adalah sebagai berikut:

$$
\begin{aligned}
& \mathrm{PE}=(10 \times 25.2) / 260 \times 100 \% \\
& \mathrm{PE}=252 / 260 \times 100 \%
\end{aligned}
$$

$\mathrm{PE}=97 \%$

Angka persentase ini menunjukkan waktu yang digunakan mesin dalam mewarnai kabel optik dibandingkan dengan waktu siklusnya.

Hasil perhitungan performance rate dari tanggal 14 Januari 2020 sampai tanggal 29 Januari 2020 tertera pada Tabel 14.

Tabel 14. Hasil Perhitungan Performance Rate

\begin{tabular}{|c|c|c|c|c|c|c|c|c|}
\hline Tanggal & $\begin{array}{c}\text { Waktu } \\
\text { Operasional } \\
\text { (menit) }\end{array}$ & $\begin{array}{c}\text { Waktu } \\
\text { Setup } \\
\text { (menit) }\end{array}$ & $\begin{array}{c}\text { Jumlah } \\
\text { Downtime }\end{array}$ & $\begin{array}{c}\text { Waktu } \\
\text { Downtime }\end{array}$ & $\begin{array}{c}\text { Jumlah } \\
\text { Unit yang } \\
\text { Diproses } \\
\text { (bobbin) }\end{array}$ & $\begin{array}{c}\text { Waktu } \\
\text { Proses } \\
\text { (menit) }\end{array}$ & $\begin{array}{c}\text { Produk } \\
\text { Cacat } \\
\text { (bobbin) }\end{array}$ & Performance \\
\hline 14 Januari 2020 & 420 & 25 & 1 & 5 & 10 & 260 & 0 & $97 \%$ \\
\hline 15 Januari 2020 & 420 & 3 & 3 & 258 & 2 & 52 & 0 & $97 \%$ \\
\hline 17 Januari 2020 & 420 & 13 & 4 & 111 & 6 & 154 & 0 & $98 \%$ \\
\hline 20 Januari 2020 & 420 & 44 & 3 & 139 & 8 & 216 & 0 & $93 \%$ \\
\hline 21 Januari 2020 & 420 & 27 & 2 & 23 & 10 & 272 & 0 & $93 \%$ \\
\hline 22 Januari 2020 & 420 & 6 & 3 & 360 & 2 & 52 & 0 & $97 \%$ \\
\hline 23 Januari 2020 & 420 & 28 & 1 & 1 & 10 & 263 & 0 & $96 \%$ \\
\hline 24 Januari 2020 & 420 & 16 & 1 & 80 & 8 & 207 & 0 & $97 \%$ \\
\hline 27 Januari 2020 & 420 & 17 & 4 & 260 & 3 & 84 & 0 & $90 \%$ \\
\hline 28 Januari 2020 & 420 & 33 & 2 & 32 & 10 & 274 & 0 & $92 \%$ \\
\hline 29 Januari 2020 & 420 & 38 & 1 & 15 & 10 & 278 & 0 & $91 \%$ \\
\hline
\end{tabular}

3. Perhitungan Quality rate (RQ)

Variabel ketiga adalah quality rate (RQ). Menggunakan rumus dapat diberikan contoh perhitungan RQ pada tanggal 14 Januari 2020 adalah sebagai berikut:

$$
\begin{aligned}
& R Q=(10-0) / 10 \times 100 \% \\
& R Q=(10) / 10 \times 100 \%
\end{aligned}
$$

$$
\mathrm{RQ}=100 \%
$$

Angka persentase ini menunjukkan jumlah bobbin kabel optik yang memiliki hasil good setelah melalui uji quality control.

Hasil perhitungan quality rate dari tanggal 14 Januari 2020 sampai tanggal 29 Januari 2020 tertera pada Tabel 15.

Tabel 15. Hasil Perhitungan Quality Rate

\begin{tabular}{|c|c|c|c|c|c|c|c|c|}
\hline Tanggal & $\begin{array}{c}\text { Waktu } \\
\text { Operasional } \\
\text { (menit) }\end{array}$ & $\begin{array}{c}\text { Waktu } \\
\text { Setup } \\
\text { (menit) }\end{array}$ & $\begin{array}{c}\text { Jumlah } \\
\text { Downtime }\end{array}$ & $\begin{array}{c}\text { Waktu } \\
\text { Downtime }\end{array}$ & $\begin{array}{c}\text { Jumlah } \\
\text { Unit yang } \\
\text { Diproses } \\
\text { (bobbin) }\end{array}$ & $\begin{array}{c}\text { Waktu } \\
\text { Proses } \\
\text { (menit) }\end{array}$ & $\begin{array}{c}\text { Produk } \\
\text { Cacat } \\
\text { (bobbin) }\end{array}$ & Quality \\
\hline 14 Januari 2020 & 420 & 25 & 1 & 5 & 10 & 260 & 0 & $100 \%$ \\
\hline 15 Januari 2020 & 420 & 3 & 3 & 258 & 2 & 52 & 0 & $100 \%$ \\
\hline 17 Januari 2020 & 420 & 13 & 4 & 111 & 6 & 154 & 0 & $100 \%$ \\
\hline 20 Januari 2020 & 420 & 44 & 3 & 139 & 8 & 216 & 0 & $100 \%$ \\
\hline 21 Januari 2020 & 420 & 27 & 2 & 23 & 10 & 272 & 0 & $100 \%$ \\
\hline 22 Januari 2020 & 420 & 6 & 3 & 360 & 2 & 52 & 0 & $100 \%$ \\
\hline 23 Januari 2020 & 420 & 28 & 1 & 1 & 10 & 263 & 0 & $100 \%$ \\
\hline 24 Januari 2020 & 420 & 16 & 1 & 80 & 8 & 207 & 0 & $100 \%$ \\
\hline 27 Januari 2020 & 420 & 17 & 4 & 260 & 3 & 84 & 0 & $100 \%$ \\
\hline 28 Januari 2020 & 420 & 33 & 2 & 32 & 10 & 274 & 0 & $100 \%$ \\
\hline 29 Januari 2020 & 420 & 38 & 1 & 15 & 10 & 278 & 0 & $100 \%$ \\
\hline
\end{tabular}

\section{Perhitungan Overall Equipment Effectiveness (OEE)}

Perhitungan OEE dibuat menjadi dua, perhitungan OEE perhari dan perhitungan OEE keseluruhan. a. Perhitungan OEE Perhari

Diberikan contoh perhitungan OEE pada tanggal 14 Januari 2020 sebagai berikut:

$\mathrm{OEE}=\mathrm{VA} \times \mathrm{PE} \times \mathrm{RQ}$ 
STRING (Satuan Tulisan Riset dan Inovasi Teknologi)

Vol. 5 No. 3 April 2021
p-ISSN: 2527 - 9661

e-ISSN: 2549 - 2837
$\mathrm{OEE}=93 \% \times 97 \% \times 100 \%$

$\mathrm{OEE}=90 \%$

Angka persentase ini menunjukkan efektifitas mesin dalam satu shift kerja selama satu hari.

Tabel 16. Hasil Perhitungan OEE Perhari

\begin{tabular}{|c|c|c|c|c|c|c|c|c|c|c|c|}
\hline Tanggal & $\begin{array}{c}\text { Waktu } \\
\text { Operasional } \\
\text { (menit) }\end{array}$ & $\begin{array}{l}\text { Waktu } \\
\text { Setup } \\
\text { (menit) }\end{array}$ & $\begin{array}{c}\text { Jumlah } \\
\text { Downtime }\end{array}$ & $\begin{array}{c}\text { Waktu } \\
\text { Downtime } \\
\text { (menit) }\end{array}$ & \begin{tabular}{|c|} 
Jumlah \\
Unit yang \\
Diproses \\
(bobbin)
\end{tabular} & $\begin{array}{l}\text { Waktu } \\
\text { Proses } \\
\text { (menit) }\end{array}$ & $\begin{array}{c}\text { Produk } \\
\text { Cacat } \\
\text { (bobbin) }\end{array}$ & Availability & Performance & Quality & $\mathrm{OEE} / d a y$ \\
\hline 14 Januari 2020 & 420 & 25 & 1 & 5 & 10 & 260 & 0 & $93 \%$ & $97 \%$ & $100 \%$ & $90 \%$ \\
\hline 15 Januari 2020 & 420 & 3 & 3 & 258 & 2 & 52 & 0 & $38 \%$ & $97 \%$ & $100 \%$ & $37 \%$ \\
\hline 17 Januari 2020 & 420 & 13 & 4 & 111 & 6 & 154 & 0 & $70 \%$ & $98 \%$ & $100 \%$ & $69 \%$ \\
\hline 20 Januari 2020 & 420 & 44 & 3 & 139 & 8 & 216 & 0 & $56 \%$ & $93 \%$ & $100 \%$ & $53 \%$ \\
\hline 21 Januari 2020 & 420 & 27 & 2 & 23 & 10 & 272 & 0 & $88 \%$ & $93 \%$ & $100 \%$ & $82 \%$ \\
\hline 22 Januari 2020 & 420 & 6 & 3 & 360 & 2 & 52 & 0 & $13 \%$ & $97 \%$ & $100 \%$ & $12 \%$ \\
\hline 23 Januari 2020 & 420 & 28 & 1 & 1 & 10 & 263 & 0 & $93 \%$ & $96 \%$ & $100 \%$ & $89 \%$ \\
\hline 24 Januari 2020 & 420 & 16 & 1 & 80 & 8 & 207 & 0 & $77 \%$ & $97 \%$ & $100 \%$ & $75 \%$ \\
\hline 27 Januari 2020 & 420 & 17 & 4 & 260 & 3 & 84 & 0 & $34 \%$ & $90 \%$ & $100 \%$ & $31 \%$ \\
\hline 28 Januari 2020 & 420 & 33 & 2 & 32 & 10 & 274 & 0 & $85 \%$ & $92 \%$ & $100 \%$ & $78 \%$ \\
\hline 29 Januari 2020 & 420 & 38 & 1 & 15 & 10 & 278 & 0 & $87 \%$ & $91 \%$ & $100 \%$ & $79 \%$ \\
\hline
\end{tabular}

Dari hasil perhitungan OEE perhari selanjutnya dibuat kedalam grafik. Terlihat dalam grafik pada Gambar 3

bahwa OEE mesin CETC 02 FO tidak stabil atau mengalami fluktuasi.

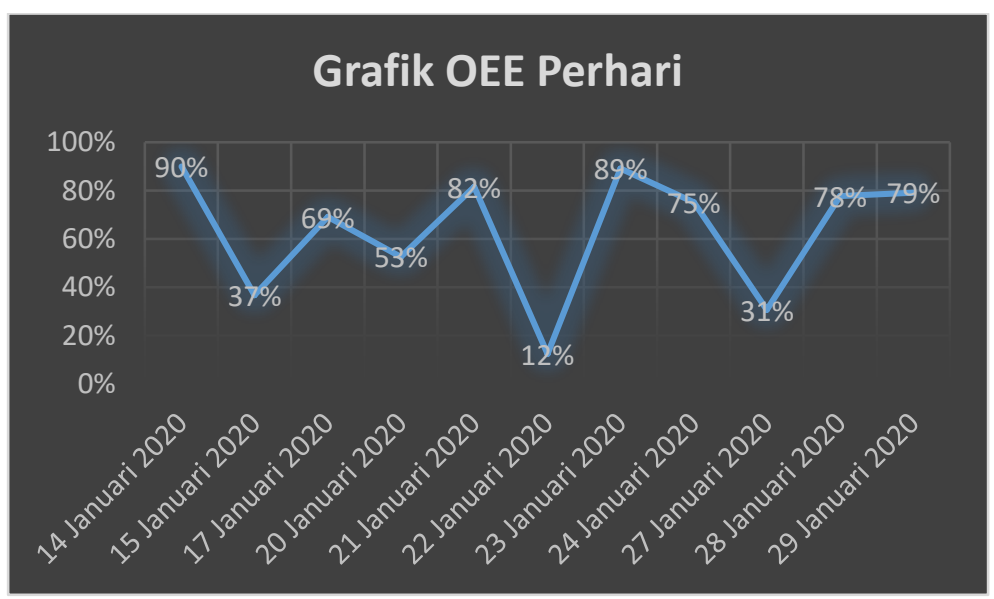

Gambar 3. Grafik OEE Perhari

b. Perhitungan OEE Keseluruhan

Perhitungan OEE keseluruhan sama dengan perhitungan OEE perhari hanya saja yang digunakan rata-rata variabel VA, PE, dan RQ sebagai berikut:

OEE Keseluruhan $=(\mathrm{VA}) \mathrm{x}(\mathrm{PE}) \mathrm{x}$ (RQ)

OEE Keseluruhan $=67 \% \times 95 \% \times$ $100 \%$

OEE Keseluruhan $=63 \%$
Angka persentase ini menunjukkan efektifitas mesin total atau rata-rata OEE dalam satu shift kerja selama 11 hari.

Hasil dapat dilihat pada Tabel 17. 
Tabel 17. Hasil Perhitungan OEE Keseluruhan

\begin{tabular}{|c|c|c|c|c|c|c|c|c|c|c|c|}
\hline Tanggal & $\begin{array}{c}\text { Waktu } \\
\text { Operasional } \\
\text { (menit) }\end{array}$ & $\begin{array}{l}\text { Waktu } \\
\text { Setup } \\
\text { (menit) }\end{array}$ & $\begin{array}{c}\text { Jumlah } \\
\text { Downtime }\end{array}$ & $\begin{array}{c}\text { Waktu } \\
\text { Downtime } \\
\text { (menit) }\end{array}$ & \begin{tabular}{|c|} 
Jumlah \\
Unit yang \\
Diproses \\
(bobbin )
\end{tabular} & $\begin{array}{l}\text { Waktu } \\
\text { Proses } \\
\text { (menit) }\end{array}$ & $\begin{array}{c}\text { Produk } \\
\text { Cacat } \\
\text { (bobbin) }\end{array}$ & Availability & Performance & Quality & $\mathrm{OEE} / d a y$ \\
\hline 14 Januari 2020 & 420 & 25 & 1 & 5 & 10 & 260 & 0 & $93 \%$ & $97 \%$ & $100 \%$ & $90 \%$ \\
\hline 15 Januari 2020 & 420 & 3 & 3 & 258 & 2 & 52 & 0 & $38 \%$ & $97 \%$ & $100 \%$ & $37 \%$ \\
\hline 17 Januari 2020 & 420 & 13 & 4 & 111 & 6 & 154 & 0 & $70 \%$ & $98 \%$ & $100 \%$ & $69 \%$ \\
\hline 20 Januari 2020 & 420 & 44 & 3 & 139 & 8 & 216 & 0 & $56 \%$ & $93 \%$ & $100 \%$ & $53 \%$ \\
\hline 21 Januari 2020 & 420 & 27 & 2 & 23 & 10 & 272 & 0 & $88 \%$ & $93 \%$ & $100 \%$ & $82 \%$ \\
\hline 22 Januari 2020 & 420 & 6 & 3 & 360 & 2 & 52 & 0 & $13 \%$ & $97 \%$ & $100 \%$ & $12 \%$ \\
\hline 23 Januari 2020 & 420 & 28 & 1 & 1 & 10 & 263 & 0 & $93 \%$ & $96 \%$ & $100 \%$ & $89 \%$ \\
\hline 24 Januari 2020 & 420 & 16 & 1 & 80 & 8 & 207 & 0 & $77 \%$ & $97 \%$ & $100 \%$ & $75 \%$ \\
\hline 27 Januari 2020 & 420 & 17 & 4 & 260 & 3 & 84 & 0 & $34 \%$ & $90 \%$ & $100 \%$ & $31 \%$ \\
\hline 28 Januari 2020 & 420 & 33 & 2 & 32 & 10 & 274 & 0 & $85 \%$ & $92 \%$ & $100 \%$ & $78 \%$ \\
\hline 29 Januari 2020 & 420 & 38 & 1 & 15 & 10 & 278 & 0 & $87 \%$ & $91 \%$ & $100 \%$ & $79 \%$ \\
\hline & & & & & & & OEE total & $67 \%$ & $95 \%$ & $100 \%$ & $63 \%$ \\
\hline
\end{tabular}

Berdasarkan Tabel 17 total OEE keseluruhan bisa didapatkan dengan beberapa cara jika data-data yang dibutuhkan sudah terkumpul dan OEE perhari sudah dihitung sebelumnya. Bisa dengan merataratakan jumlah OEE/day, merataratakan availability rate, performance rate, dan quality rate terlebih dahulu lalu dikalilkan, atau dengan menjumlahkan semua data lalu dihitung seperti menghitung OEE perhari. Semuanya akan mendapatkan hasil yang sama yaitu $63 \%$.

\section{SIMPULAN}

Dalam satu shift kerja selama 11 hari dari tanggal 14 Januari 2020 sampai 29 Januari 2020 mesin CETC 02 Coloring FO mendapatkan: Total waktu tersedia mesin (Availability) keseluruhan adalah $67 \%$ yang masih jauh di bawah standar global yaitu $90 \%$. Total kemampuan produksi (Performance) keseluruhan adalah 95\% yang sudah memenuhi standar global yaitu 95\%. Total produksi sesuai standar (Quality) keseluruhan adalah $100 \%$ yang berada di atas standar global yaitu $99 \%$. Total efektifitas mesin (Overall Equipment Effectiveness) keseluruhan adalah 63\% yang berada di atas batas kewajaran standar benchmark Japan Institute of Plant Management (JIPM) yaitu 60\%. Dari hasil yang diperoleh, diketahui bahwa dari ketiga variabel OEE yang membuat persentase nilai OEE kecil adalah availability rate. Hal ini dikarenakan banyak hal yang mengharuskan mesin berhenti, baik yang disengaja atau tidak disengaja. Pada tanggal 22 Januari 2020 tercatat waktu downtime paling besar yaitu 360 menit karena saat itu mesin bermasalah dan tidak boleh dioperasikan sebelum ditangani oleh bagian maintenance.

\section{DAFTAR PUSTAKA}

[1] M. Yahya, "Era Industri 4.0: Tantangan Dan Peluang Perkembangan Pendidikan Kejuruan Indonesia," Orasi Ilm. Profr. Bid. Ilmu Pendidik. Kejuru. Univ. Negeri Makassar, 2018.

[2] A. A. Sibarani, K. Muhammad, and A. Yanti, "Analisis Total Productive Maintenance Mesin Wrapping Line 4 Menggunakan Overall Equipment Effectiveness dan Six Big Losses di PT XY , Cirebon - Jawa Barat Total Productive Maintenance Analysis of Wrapping Machine Line 4 through Overall Equipment Effectiveness and Six Big Losses at PT XY, Cirebon - West Java," vol. 7, 2020. 
[3] Hermanto, "Pengukuran Nilai Overall Equipment Effectiveness pada Divisi Painting di PT. AIM," J. Metris, vol. 17, pp. 97-106, 2016.

[4] M. R. Rifaldi, "Overall Equipment Effectiveness (OEE) Pada Mesin Tandem 03 Di PT. Supernova Flexible Packaging," J. Rekayasa Ind., vol. 2, no. 2, pp. 67-77, 2020, doi: 10.37631/jri.v2i2.180.

[5] S. D. Cahyono and N. Budiharti, "Implementasi Total Productive Maintenance Pada Mesin Press Dryer Di Pt. Tri Tunggal Laksana," Ind. Inov. J. Tek. Ind., vol. 10, no. 2, pp. 75-81, 2020, doi: 10.36040/industri.v10i2.2827.

[6] L. Gozali, F. Y. Daywin, and C. O. Doaly, "Root Cause Analysis and Overall Equipment Effectiveness of Press Machine in Line $\mathrm{H}$ and Hirac At Pt. Xyz," J. Muara Sains, Teknol. Kedokt. dan Ilmu Kesehat., vol. 4, no. 2, p. 285, 2020, doi: 10.24912/jmstkik.v4i2.8735.

[7] P. Simamora and B. Tambun, "Analisa Perhitungan Overall Equipment Effectiveness (OEE) Pada Proses Awal Pengolahan
Kelapa Sawit Di PT. Perkebunan Nusantara IV Gunung Bayu," Tapanuli Journals, vol. 2, no. 1, pp. 35-49, 2019.

[8] S. Dwi Cahyono, F. Handoko, and N. Budiharti, "Penerapan Efektivitas Mesin Debarker Menggunakan Overall Equipment Effectiveness (Studi pada PT. Tri Tunggal Laksana Unit Blitar)," J. Teknol. Dan Manaj. Ind., vol. 6, no. 2, pp. 12-17, 2020, doi: 10.36040/jtmi.v6i2.3012.

[9] W. Gorapetha, J. Hutabarat, and L. a Salmia, “... Effectiveness Untuk Meminimumkan Nilai Six Big Losses Di Mesin Produksi Dan Usulan Perbaikan Dengan Metode Kaizen 5S Di Cv ...," J. Valtech, vol. 3, no. 2, pp. 219-225, 2020, [Online]. Available: https://ejournal.itn.ac.id/index.php/v altech/article/view/2767.

[10] Firdaus, F. A. Pradana, and E. Indarto, "Performansi Jaringan Fiber Optik Dari Sentral Office Hingga Ke Pelanggan Di Yogyakarta," J. Elektro Telekomun. Terap., vol. 2, pp. 207-214, 2016. 